\title{
Economic Benefit of Melting Low Manganese Pig Iron
}

\author{
Jimoh S. O ${ }^{1}$, Lozovich, $S^{2}$ And Nwuguru A. $A^{3}$ \\ Materials \& Metallurgical Engineering, Faculty of Engineering, Ambrose Alli University, Ekpoma, Edo State, Nigeria ${ }^{1,3}$ \\ Department of Iron and Steel Making, Institute of Materials Science and Metallurgy, \\ Ural Federal University, Ekaterinburg, Russia ${ }^{2}$
}

\begin{abstract}
The study about economic effectiveness of melting low Manganese pig iron is presented. In this study, mathematical models were developed to evaluate of the economic effectiveness of the exclusion of the use of Manganese ore in agglomeration and blast furnace process with its transfer to converter process. It was found that by obviating the use of manganese ore in blast furnace, there is economy of resources and reduction in the cost of liquid pig iron. The processing of low manganese Pig-iron in a converter with the use of manganese ore also created positive economic effect, and it can get up to $6.4 \mathrm{USD} /$ ton of steel.
\end{abstract}

Keywords: Economic Benefit; Mathematical models; blast furnace process; melting low manganese pig-iron and steel.

\section{INTRODUCTION}

Manganese is one of the most common additives in pig iron and steel. In many cases, it plays a positive role; ore prominent is its action on the formation of slag in oxygen-converter process at the formation of melting, when the lime has not been charged. Before 1970s, in the practice of oxygen-converter process, it was a compulsory requirement to have not less than $0.8 \%$ Manganese in the pig iron. This requirement formed the basis for the construction of oxygenconverter unit in Ajaokuta Steel Company (Nigeria). For this purpose, it is required for the use of manganese ore in agglomeration charged materials.

The use of manganese ore in blast furnace burden increases the cost of pig iron not only because of the high cost of manganese ore, but also as a result of the increase in the slag formed which leads to the increase in specific expense of firing coke on the melting of pig-iron and decrease in the productivity of blast furnace shop. The development of blast furnace process and improvement of preparation of charge materials for smelting for the purpose of improving the features of blast furnaces have resulted in the drastic reduction of the quantity of manganese ore charged. The content of manganese in pig-iron is reduced to $0.1-0.3 \%$ and below [1].

In modern times, the technology of converter melting is adopted to reprocessing of such pig-iron [2], However, there are some indications of lower performance index in comparison with that of pig-iron with high content of manganese. A new technology has been proposed by Bigeyer for the processing of low manganese pig-iron in oxygen-converter [3]. The technology stipulates that the melting is carried out in double slag regime. At the end of the first regime, it is possible to carry out complete discharge of the slag and in the second regime, manganese ore is charged both in a required amount for the deoxidization and for alloying the melt with manganese; slag of the second regime is completely used during the next melting.

\section{METHOD}

In this study, mathematical models were developed to evaluate the economic effectiveness of the exclusion of the use of manganese ore in agglomeration and blast furnace process with its heat transfer to the converter process. The main economic benefits are the reduction in the total consumption of manganese ore in metallurgical complex, including agglomeration-blast furnace and steel making and the exclusion of the consumption of Ferro-manganese for the deoxidization and alloying of steel.

In according with the technical specification for the construction of Ajaokuta Steel Industry, consumption of manganese ore containing $28.5 \% \mathrm{Mn}$ and $30 \% \mathrm{SiO}_{2}$, in the agglomeration charge, is $63.95 \% \mathrm{~kg} /$ ton of pig-iron, and the consumption of ferro-manganese with $75 \% \mathrm{Mn}$ for the deoxidation of carbon killed steel with $0.5 \% \mathrm{Mn}$ is equal to $10.6 \mathrm{~kg} / \mathrm{ton}$ of steel. 
International Journal of Innovative Research in Electrical, Electronics, Instrumentation and Control Engineering

Vol. 8, Issue 9, September 2020

\section{DOI 10.17148/IJIREEICE.2020.8903}

Our computations showed that with the converter melting by the new technology for keeping in the end product metal a manganese content of $0.50 \%, 21 \mathrm{~kg} /$ ton of steel manganese ore with $35 \%$ Mn content is required.

The removal of manganese ore from agglomeration production, as shown by the calculation, leads to a reduction in the consumption of coke by $20 \mathrm{~kg} /$ ton of cast iron mainly by way of reducing the consumption of slag and almost complete absence of endothermic reaction process of the reduction of manganese. At the price of $1 \% \mathrm{Mn}$ in a ton of ore $2.75-$ 2.95USD/ton [4], coke 80-100USD/ton [5] and ferromanganese 480-520USD/ton [6], excluding the use of manganese ore in blast furnace process provides economy of 6.996USD/ton of pig-iron, and in the production of low manganese pig-iron in converter with the new technology in the situation of Ajaokuta Metallurgical Industry, the general economic effect of 6.73USD ton of steel.

\section{CONCLUSION}

By obviating the use of manganese ore in blast furnace, there is economy of resources and reduction in the cost of pigiron. In the case of Ajaokuta Metallurgical Industry, this reduction in the cost of pig-iron may be up to 7USD/ton of pigiron. The processing of low manganese pig-iron in a converter with the use of manganese ore also created positive economic effect, and it can get up to 6.4USD ton of steel.

\section{REFERENCES}

[1]. Energy efficient technology to produce hot metal from titania-magnetite ore/AISTech 2016 Iron and Steel Technology Conference, Pittsburgh; United States; $16^{\text {th }}$ may to $19^{\text {th }}$ may 2016 ; code 122631

[2]. Melting and Reformation of low manganese pig Iron/TP. Ural Scientific and Research Institution for Ferrous Metals. Sverdlovsk, 1983 , P115.

[3]. Kolpakov S.V. and others. The Technology of Steel Production in Modern Converter Sections: M. Mashinostroyenye, 1991. P464.

[4]. Grishenko S. G. Seminar on the problem of Manganese/Steel 1993. No. 12. P29.

[5]. Yufin U. C. priority problems of agglomeration Production/Steel 1993. No.4-9. 